\author{
О.Б. Леонтьєв, Д.В. Бердочник, А.Д. Бердочник
}

Харківський національний університет Повітряних Сил ім. І. Кожедуба, Харків

\title{
УДОСКОНАЛЕННЯ МЕТОДИКИ ПОРІВНЯЛЬНОГО ОЦІНЮВАННЯ РІЗНИХ ТИПІВ РЕАКТИВНИХ НАВЧАЛЬНО-ТРЕНУВАЛЬНИХ (НАВЧАЛЬНО-БОЙОВИХ) ЛІТАКІВ
}

\begin{abstract}
Проведено аналіз існуючих методичних підходів для порівняльного очінювання реактивних навчальнобойових (навчально-тренувальних) літаків та проаналізовано недоліки при практичному використанні кожного методичного підходу. Запропоновано удосконалення існуючої методики визначення кваліметричного значення ступеню пристосованості до базової льотної підготовки курсантів шляхом заміни вхідних факторів початкового простору методики на допоміжні інтерполяційні моделі, до початкових даних, які увійшли в характеристики літака, значення котрих є доступними з наявних джерел науково-технічної інформації. Проведена оиінка отриманих допоміжних моделей за умовами точності апроксимації та правильності поведінки факторів при зміні значень вхідних параметрів.
\end{abstract}

Ключові слова: порівняльне оцінювання, навчально-тренувальні (навчально-бойові) літаки, факторний простір, кваліметрична модель, допоміжна інтерполяиійна модель.

\section{Вступ}

Постановка проблеми. На даний час реактивний навчально-бойовий літак Л-39С є літаком для забезпечення базової навчальної льотної підготовки курсантів льотного профілю навчання. Аналізуючи стан існуючого парку навчальних літальних апаратів Л-39С, можна зробити висновок, що експлуатація літаків наближається до граничного стану, після чого їх подальша експлуатація повинна бути припиненою не залежно від їх технічного стану. Тому, для забезпечення безперервної підготовки льотних кадрів існує актуальна проблема оновлення існуючого парку навчальних авіаційних частин (підрозділів) сучасними реактивними навчально-бойовими літаками [1].

Для вибору типу навчально-бойового літака, за рахунок якого доцільно оновити існуючий парк літаків даного класу в найкращий спосіб, потрібна методика порівняльного оцінювання типів літаків щодо ступеню їх придатності для використання в базовій навчальній льотній підготовці (далі - НЛП) курсантів.

Аналіз останніх досліджень і публікацій. Методичні підходи до порівняльного оцінювання різних типів літаків, в тому числі реактивних навчально-тренувальних та навчально-бойових, що на цей час відомі та застосовуються для вирішення практичних задач, умовно можна поділити на три основні групи. Перша група підходів грунтується на попарному порівнянні значень основних тактикотехнічних характеристик літальних апаратів однакового призначення. Прикладами такого підходу є ті, що викладені в роботах [2-3]. Такі підходи дозво- ляють отримати оцінку двох зразків авіаційної техніки щодо належності їх до того або іншого покоління літальних апаратів певного призначення, але не дають однозначної відповіді на запитання щодо переваги порівнювальних зразків стосовно ступеню їх придатності до виконання завдань за призначенням. Друга група методичних підходів базується на використанні інтегрального (узагальненого) показника воєнно-технічного рівня зразка озброєння та військової техніки. На відміну від попередніх, такі підходи дозволяють отримати значення одного інтегрального показника якості зразка, за ознакою максимуму якого, надавати перевагу тому, або іншому літаку, які порівнюються. Прикладами таких підходів $є$ такі, що викладені в роботах [4-9]. В той же час, сам показник воєнно-технічного рівня пов'язаний із ступенем впровадження в конструкцію та бортове обладнання літака передових технологічних рішень, але безпосередньо виявляється непов'язаним із кількісною оцінкою ступеню пристосованості зразка до виконання задач за його призначенням.

До третьої групи методичних підходів до порівняльного оцінювання реактивних навчальнобойових та навчально-тренувальних літаків можна віднести підхід, обгрнутований на введенні комплексного показника технічно-економічної досконалості літака, детально викладений в роботах [10-11]. Такий підхід дозволяє комплексно врахувати пристосованість літака до виконання завдань за призначенням у співвідношенні до узагальненої вартості льотної години, та цілком придатний для синтезу тактико-техніко-економічного обрису перспективного навчально-бойового літака та його силової 
установки. При всій привабливості такого методичного підходу, він базується на використанні занадто великої кількості початкових даних про конкретні технічні рішення, котрі планується впроваджувати при створенні перспективного або модернізованого зразка авіаційної техніки та не дуже підходить для розв'язування практичних задач порівняльного оцінювання літаків, що виставлені на світовому ринку озброєнь, детальна й точна інформація про характеристики яких не міститься у прямому доступі. Крім того, складова названого комплексного показника дозволяє оцінити літак по придатності до застосування у системі бойової підготовки льотного складу та не враховує особливості навчальної льотної підготовки курсантів. Від останнього недоліку вільний методичний підхід, викладений в [12-13], в якому в якості показника результативності використання реактивного навчально-бойового (навчальнотренувального) літака в базовій льотній підготовці використовуються коефіцієнти ступеня пристосованості літака до базової (початкової та основної) навчальної льотної підготовки курсантів. Даний методичний підхід базується на використанні кваліметричних моделей навчальних властивостей літака [14], фактори яких обумовлені результатами аналізу програм та вправ навчальної льотної підготовки курсантів [15-16], а значення коефіцієнтів при факторах моделі - визначені на основі обробки результатів експертного опитування репрезентивної групи досвідчених льотчиків-інструкторів, що мають досвід у проведенні навчальної льотної підготовки курсантів [17]. Значення факторів кваліметричних моделей [14] являють собою значення тактикотехнічних характеристик (ТТХ) типів навчальнобойових (НБЛ) та навчально-тренувальних літаків (НТЛ), які підлягають порівняльному оцінюванню, та складають основу системи початкових даних у відповідній методиці [12-13]. Для визначення значень ТТХ літаків, для яких виникають труднощі в отриманні з наявних джерел науково-технічної інформації, запропоновано використання двох часткових методик - методики розрахунку аеродинамічних характеристик літаків на основі наближених інженерних методів, та методики прямого експертного визначення значення характеристик літака. Але дані часткові методики не дозволяють вирішити проблему формування початкових даних в повному обсязі, тому що стикаються 3 додатковими ускладненнями в отриманні початкових даних, а можливості застосування експертних методів - стримується внаслідок відсутності достатньої для досягнення узгоджених колективних оцінок кількості досвідчених експертів. Саме усунення названих недоліків і обумовлює напрями удосконалення методики порівняльного оцінювання різних типів реактивних НБЛ (НТЛ) за ступенем пристосованості до навчальної льотної підготовки курсантів. В якості шляху, за допомогою реалізації якого можливо усунути труднощі у формуванні початкових даних про ТТХ типів НБЛ (НТЛ), які підлягають оцінюванню, пропонується розробити допоміжні інтерполяційні моделі, що побудовані на використанні накопиченого досвіду створення таких НБЛ (НТЛ), та являють собою наближені функціональні залежності факторів кваліметричних моделей [14] та інших ТTХ літака, значення яких $є$ доступними з наявних джерел науковотехнічної інформації.

Метою статті $є$ дослідження можливих шляхів удосконалення методики порівняльного оцінювання різних типів реактивних НБЛ (НТЛ) за ступенем пристосованості до навчальної льотної підготовки курсантів на основі побудови допоміжних функціональних залежностей факторів існуючих кваліметричних моделей від доступних для визначення 3 джерел науково-технічної інформації ТТХ типів літаків.

\section{Виклад основного матеріалу}

У роботах [15] та [16] було проаналізовано діючі системи навчальної льотної підготовки курсантів та обгрунтовано початкове обрання переліку TTX літака, які увійшли до факторного простору для побудови кваліметричних моделей ступеня пристосованості літака до забезпечення виконання завдань початкової та основної НЛП курсантів. До факторного простору даних моделей увійшли десять факторів, які на основі експертного опитування виявилися найбільш значимими у прояві впливу на пристосованість літака для використання за призначенням, а саме: допустимий кут атаки $\alpha_{\text {доn }}$; максимальна аеродинамічна якість $K_{\max }$; поздовжнє перевантаження $n_{x}$; швидкість відриву $V_{\text {відр }}$; максимальне нормальне експлуатаційне перевантаження $n_{y \text { max }}^{e}$; посадковий кут атаки $\alpha_{n o c}$; посадкова швидкість $V_{n o c}$; мінімальна допустима швидкість горизонтального польоту $V_{\min }$ доn ; прийомистість двигунів $t_{n p с y}$; тягоозброєність $\mu$.

За підсумками проведеного аналізу наявних джерел технічної інформації про літаки даного класу, а також інформації, яку виробник надає при оформленні технічної пропозиції [2-3; 11; 18; 21-22], було сформовано перелік ТТХ, значення яких можуть бути визначеними 3 такого роду джерел. Такий перелік наведено в табл. 1. Аналізуючи вище наведені дані можна визначити перелік факторів кваліметричної моделі НБЛ (НТЛ), для якого доцільно побудувати допоміжні моделі на полі нових факторів - ТТХ літаків даного класу, про значення яких для реалізованій в практиці світового авіабудування 
типів реактивних НБЛ (НТЛ) не можливо зібрати дані. До такого переліку входять:

- прийомистість силової установки;

- мінімальна допустима швидкість горизонтального польоту;

- швидкість відриву;
- швидкість посадкова;

- посадковий кут атаки;

- максимальний допустимий кут атаки;

- максимальна аеродинамічна якість;

- максимальне наявне повздовжнє перевантаження.

Таблиця 1

Перелік факторів кваліметричної моделі та ТТХ НБЛ (НТЛ), значення яких можуть бути визначеними з джерел технічної інформації

\begin{tabular}{|c|c|c|}
\hline \multirow{2}{*}{$\begin{array}{c}\text { Фактори } \\
\text { кваліметричної моделі }\end{array}$} & \multicolumn{2}{|c|}{ Доступні з джерел технічної інформації } \\
\hline & ТТХ НБЛ (НТЛ) & $\begin{array}{c}\text { ТТХ силової установки } \\
\text { НБЛ (НТЛ) }\end{array}$ \\
\hline $\begin{array}{l}\text { допустимий кут атаки } \alpha_{д о n} ; \\
\text { максимальна аеродинамічна якість } \\
K_{\text {max }} ; \\
\text { поздовжнє перевантаження } n_{x} ; \\
\text { швидкість відриву } V_{\text {відp }} ; \\
\text { максимальне нормальне } \\
\text { експлуатаційне перевантаження } \\
n_{y \text { тах }}^{e} ; \\
\text { посадковий кут атаки } \alpha_{n о c} ; \\
\text { посадковаа швидкість } V_{\text {пос }} ; \\
\text { мінімальна допустима швидкість } \\
\text { горизонтального польоту } V_{\min } \text { доn } \\
\text { прийомістись двигунів } t_{n p с y} ; \\
\text { тягоозброєність } \mu .\end{array}$ & 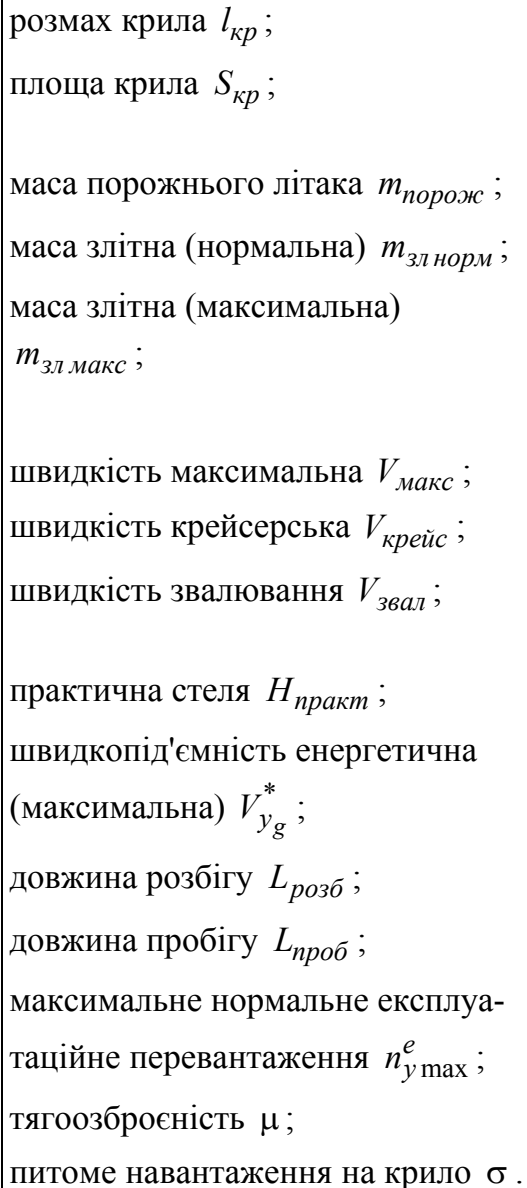 & 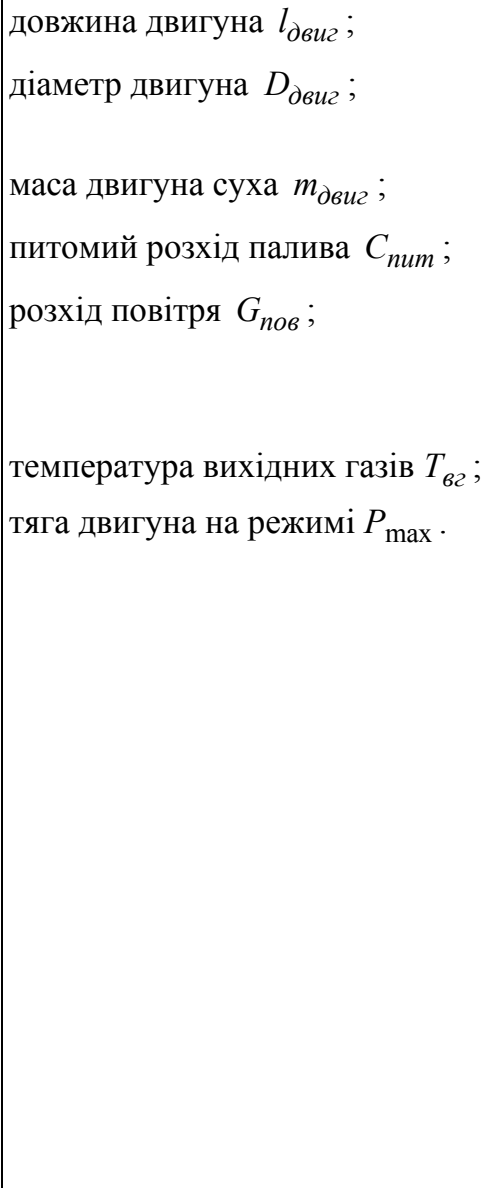 \\
\hline
\end{tabular}

Джерело: розроблено авторами за даними [2-3; 11; 18; 21-22].

Для аналізу зв'язків визначених факторів скористаємося відомими з теорії аеродинаміки та динаміки польоту літака [19-20] відомостями про фізичну залежність перелічених факторів від інших параметрів польоту та ТТХ літака.

В роботі [16] був проведений аналіз взаємозв'язку параметрів мінімально допустимої швидкості польоту $V_{\min }$ до та швидкості звалювання $V_{\text {зв }}$. Було знайдено зв'язок між цими параметрами, оскільки між собою пов'язані допустимий кут атаки $\alpha_{\partial о n} \mathrm{i}$

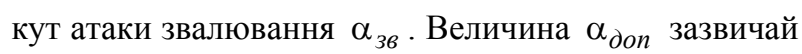
призначається на 3-5 ${ }^{\circ}$ менше, ніж $\alpha_{36}$. Також взаємний зв'язок існує між коефіцієнтом піднімальної сили звалювання $C_{y_{a} \text { зв}}$, який дорівнює максималь-

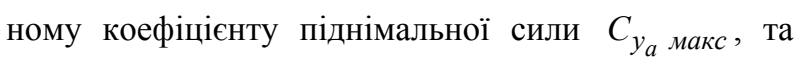
допустимим коефіцієнтом піднімальної сили

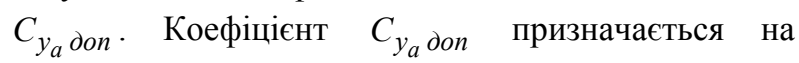
$10 \ldots 20 \%$ менше, ніж $C_{y_{a} \text { зв }}$. Тому для спрощення збору початкових даних кваліметричної моделі НБЛ (НТЛ) доцільно замість фактору мінімально допустимої швидкості польоту обрати фактор швидкості звалювання, значення про який $є$ у вільному доступі в наявних джерелах інформації для всіх без виключення літаків даного класу і які виробник зазвичай надає при оформленні технічної пропозиції. 
Наступним параметром літака, який слід замінити, є максимальна аеродинамічна якість $K_{\max }$. Незалежно від характеру руху літака, його лобовий опір пов'язаний $з$ підйомною силою через аеродинамічну якість планеру літака $K$ :

$$
K=\frac{Y_{a}}{X_{a}},
$$

де $Y_{a}$ - піднімальна сила;

$$
X_{a} \text { - сила опору. }
$$

У прямолінійному горизонтальному польоті виконується умова рівності піднімальної сили та ваги $G$ літака $Y_{a}=G$, тоді

$$
K=\frac{G}{X_{a}} .
$$

Умова прямолінійності горизонтального польоту $Y_{a}=G$ дозволяє встановити зв'язок між швидкістю польоту і коефіцієнтом підйомної сили

$$
Y_{a}=\frac{C_{y_{a}} \rho_{H} V^{2}}{2} \cdot S=G,
$$

де $S$ - площа крила;

$V$ - швидкість польоту літака;

$\rho_{H}-$ густина повітря на заданій висоті польоту.

Розглянемо силу лобового опору та ії залежність від швидкості польоту. Вона визначається за відомою з теорії аеродинаміки формулою

$$
X_{a}=C_{x_{a}} \frac{\rho_{H} V^{2}}{2} S,
$$

де $C_{x_{a}}$ - коефіцієнт лобового опору.

Максимальна аеродинамічна якість $K_{\max }$ відповідає найвигіднішому куту атаки $\alpha_{н в}\left(C_{y_{a} \mu в}\right) \mathrm{i}$, відповідно, найвигіднішій швидкості польоту $V_{н в}$

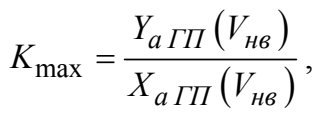

де $Y_{a \text { ГП }}\left(V_{н в}\right)$ - піднімальна сила горизонтального польоту при найвигіднішій швидкості польоту;
$X_{a \text { ГП }}\left(V_{н в}\right)$ - сила лобового опору горизонтального польоту при найвигіднішій швидкості польоту.

При умові сталого прямолінійного польоту, коли піднімальна сила літака дорівнює його вазі, а лобовий опір - тязі силової установки, вираз (5) приймає наступний вигляд:

$$
K_{\max }=\frac{G}{P_{\mu в}} \approx \frac{m_{3 л} g}{a \cdot P_{\max }},
$$

де $P_{н в}$ - тяга силової установки при найвигіднішій швидкості;

$P_{\max }$ - максимальна тяга силової установки;

$a$ - усереднений коефіцієнт залежності величини максимальної тяги двигуна від значення тяги при найвигіднішій швидкості.

Аналізуючи вираз (6) можна зробити висновок, що параметр максимальної аеродинамічної якості залежить від максимальної тяги силової установки та злітної маси літака. Але в якості факторів кваліметричної моделі можливо використати більш інформативні комплексні характеристики літака, які характеризують аеродинамічну якість, а саме питоме навантаження на крило $\sigma$ та тягоозброєність літака $\mu$. Таким чином максимальну аеродинамічну якість можна представити як деяку функцію:

$$
K_{\max }=f(\sigma ; \mu) .
$$

Для знаходження наближеного вигляду залежності (7) за допомогою відомого методу групового урахування аргументів (МГУА) було зібрано з наявних джерел технічної інформації [2-3; 21-22] статистичний матеріал про вже відомі значення параметрів реалізованих в світовій практиці навчальнобойових (навчально-тренувальних) літаків та їх ТTХ зі складу обраного факторного простору. Для побудови наближених моделей, апроксимуючих невідому залежність виду (7) було зібрано дані про відповідні характеристики 37-ми реалізованих у світовій практиці різних навчально-бойових (навчальнотренувальних) літаків. Дані, яких 3 метою підвищення якості обробки даного статистичного матеріалу методом найменших квадратів було нормовано відносно аналогічних значень ТТХ літака-еталона Л-39, представлені в табл. 2.

Таблиця 2

Нормовані відносно аналогічних значень ТТХ літака-еталона Л-39 початкові дані для апроксимації невідомої залежності (7) та розрахункові значення шуканої величини

\begin{tabular}{|c|c|c|c|c|}
\hline Тип літака & Тягооброєнність & $\begin{array}{c}\text { Питоме } \\
\text { навантаження } \\
\text { на крило }\end{array}$ & $\begin{array}{c}\text { Максимальна } \\
\text { аеродинамічна якість }\end{array}$ & $\begin{array}{c}\text { Максимальна } \\
\text { аеродинамічна якість } \\
\text { розрахункова }\end{array}$ \\
\hline 1 & 2 & 3 & 4 & 5 \\
\hline T-33А (B) & 1,13 & 1,09 & 0,94 & 1,05 \\
\hline $\begin{array}{c}\text { DH-115 “Vampire” } \\
\text { T.Mk-11 }\end{array}$ & 0,76 & 0,83 & 1,49 & 1,35 \\
\hline
\end{tabular}


Закінчення табл. 2

\begin{tabular}{|c|c|c|c|c|}
\hline 1 & 2 & 3 & 4 & 5 \\
\hline CM-170 "Magister" & 0,74 & 0,68 & 1,41 & 1,34 \\
\hline $\mathrm{T}-37 \mathrm{~B}(\mathrm{C})$ & 0,87 & 0,68 & 1,13 & 1,19 \\
\hline MS.760 "Paris" & 0,77 & 0,76 & 1,42 & 1,32 \\
\hline P-84 "Jet Provost" T.Mk-4 & 0,86 & 0,72 & 1,29 & 1,21 \\
\hline "Gnat" T.Mk-1 & 1,44 & 0,89 & 0,72 & 0,79 \\
\hline $\mathrm{T}-1 \mathrm{~A}(\mathrm{C})$ & 1,15 & 0,78 & 0,97 & 0,96 \\
\hline MB-326G (GB) & 0,92 & 0,95 & 1,18 & 1,21 \\
\hline L-29 "Delfi" & 0,72 & 0,69 & 1,40 & 1,37 \\
\hline TS-11 "Iskra" & 0,69 & 0,90 & 1,35 & 1,45 \\
\hline CL-41 (CT-114) “Tutor” & 1,05 & 0,68 & 0,98 & 1,02 \\
\hline T-38A (B) "Talon" & 1,77 & 1,38 & 0,79 & 0,76 \\
\hline $\mathrm{T}-2 \mathrm{~B}(\mathrm{C})$ & 1,28 & 1,00 & 0,76 & 0,91 \\
\hline G-2A "Galeb" & 0,78 & 0,80 & 1,33 & 1,32 \\
\hline Saab-105 (Sk-60) & 1,09 & 1,03 & 0,94 & 1,07 \\
\hline BAC-167 "Strikemaster" & 0,86 & 1,00 & 1,18 & 1,29 \\
\hline L-39 "Albatros" & 1,00 & 1,00 & 1,00 & 1,14 \\
\hline "Hawk" T Mk.1 & 1,23 & 1,25 & 0,85 & 1,01 \\
\hline "Alpha Jet" & 1,42 & 1,19 & 0,98 & 0,87 \\
\hline MB-339A & 1,09 & 0,95 & 1,14 & 1,05 \\
\hline HJT-16 “Kiran-II” Mk.2 & 1,18 & 0,93 & 0,92 & 0,97 \\
\hline C.101 "Aviojet" & 0,91 & 1,01 & 1,32 & 1,24 \\
\hline G-4 (M) "Super Galeb" & 1,02 & 1,00 & 1,22 & 1,13 \\
\hline AT-3A (B) "Tsu Chiang" & 1,58 & 1,00 & 0,88 & 0,74 \\
\hline S.221 & 1,09 & 0,91 & 0,98 & 1,04 \\
\hline IA-63 "Pampa" & 1,10 & 1,01 & 1,11 & 1,06 \\
\hline $\mathrm{T}-4$ & 1,53 & 1,13 & 0,79 & 0,79 \\
\hline JAR-99 "Soim" & 1,09 & 0,98 & 1,08 & 1,06 \\
\hline L-59 (L-39MS) & 1,07 & 1,19 & 1,12 & 1,12 \\
\hline I-22 "Iryda" & 1,19 & 1,39 & 1,05 & 1,08 \\
\hline "Hawk-100" & 1,36 & 1,28 & 1,21 & 0,93 \\
\hline T-45 "Goshawk" & 1,21 & 1,44 & 1,03 & 1,07 \\
\hline JL-8 (K-8) “Karakorum" & 1,18 & 0,93 & 0,93 & 0,97 \\
\hline TA-4J Skyhawk & 1,38 & 1,27 & 1,02 & 0,91 \\
\hline M.346 "Master" & 2,19 & 1,21 & 0,59 & 0,67 \\
\hline Yak-130 & 1,97 & 1,20 & 0,71 & 0,68 \\
\hline
\end{tabular}

Джерело: розроблено авторами за даними [2-3; 21-22].

Для визначення виду апроксимуючої функції було сформовано чотири їх альтернативні форми, які показані в табл. 3.
В табл. 3 невідомі значення вільного члену позначено як $a_{0}$, а невідомі коефіцієнти при відповідних факторах - через $a_{\sigma} ; a_{\mu} ; a_{\sigma \mu} ; a_{2 \sigma} ; a_{2 \mu}$.

Альтернативні форми апроксимуючих моделей для невідомої залежності (7)

\begin{tabular}{|c|c|}
\hline Номер форми та кількість факторів & Форма запису моделі \\
\hline 1 & 2 \\
\hline форма № $1-(2$ фактора $)$ & $\bar{K}_{\max }=a_{0}+a_{\mu} \cdot \bar{\mu}+a_{\sigma} \cdot \bar{\sigma}$ \\
\hline
\end{tabular}




\begin{tabular}{|c|c|}
\hline 1 & 2 \\
\hline форма № 2-(3 фактора) & $\bar{K}_{\max }=a_{0}+a_{\mu} \cdot \bar{\mu}+a_{\sigma} \cdot \bar{\sigma}+a_{2 \mu} \cdot \bar{\mu}^{2}$ \\
\hline форма № 3-(4 факторів) & $\bar{K}_{\max }=a_{0}+a_{\mu} \cdot \bar{\mu}+a_{\sigma} \cdot \bar{\sigma}+a_{2 \mu} \cdot \bar{\mu}^{2}+a_{2 \sigma} \cdot \bar{\sigma}^{2}$ \\
\hline форма № 4-(5 факторів) & $\bar{K}_{\max }=a_{0}+a_{\mu} \cdot \bar{\mu}+a_{\sigma} \cdot \bar{\sigma}+a_{2 \mu} \cdot \bar{\mu}^{2}+a_{2 \sigma} \cdot \bar{\sigma}^{2}+a_{\mu \sigma} \cdot \bar{\mu} \bar{\sigma}$ \\
\hline
\end{tabular}

Джерело: розроблено авторами.

В якості критерію вибору кращої з них, було обрано значення відносної похибки апроксимації, яке повинне бути меншим, ніж задане $\delta_{\max }<25 \%$. Значення відносної похибки апроксимації обчислюється за відомими виразом:

$$
\delta_{\text {max }}=\max _{j=1, N}\left(\frac{\left.\mid \bar{X}_{\text {реал } j-\bar{X}_{\text {розр } j}^{*} \mid}^{*}\right) \%,}{\bar{X}_{\text {реал } j}^{*}},\right.
$$

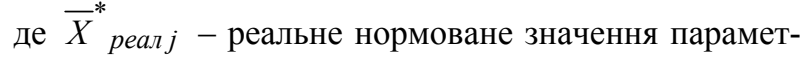
ру $j$-го літака;

\section{$\bar{X}_{\text {розр }}^{*}$ - розрахункове нормоване значення} параметру $j$-го літака.

За допомогою методу найменших квадратів було знайдено значення коефіцієнтів при відповідних факторах для всіх представлених альтернативних формах та розраховано значення відносної похибки апроксимації для кожної форми, що наведені в табл. 4.

Альтернативні форми апроксимуючих моделей для невідомої залежності (7)

Таблиця 4 з відповідними значеннями відносної похибки апроксимації

\begin{tabular}{|c|c|c|}
\hline № форми & Форма запису моделі & $\delta_{\max }$ \\
\hline форма № 1 & $\bar{K}_{\max }=1,65-0,59 \cdot \bar{\mu}+0,09 \cdot \bar{\sigma}$ & 29,7 \\
\hline форма № 2 & $\bar{K}_{\max }=2,26-1,78 \cdot \bar{\mu}+0,24 \cdot \bar{\sigma}+0,42 \cdot \overline{\mu^{2}}$ & 22,8 \\
\hline форма № 3 & $\bar{K}_{\max }=2,53-1,72 \cdot \bar{\mu}-0,36 \cdot \bar{\sigma}+0,41 \cdot \bar{\mu}^{2}+0,29 \cdot \bar{\sigma}^{2}$ & 22,2 \\
\hline форма № 4 & $\bar{K}_{\max }=2,6-1,92 \cdot \bar{\mu}-0,33 \cdot \bar{\sigma}+0,02 \cdot \bar{\mu}^{2}-0,37 \cdot \bar{\sigma}^{2}+1,12 \cdot \bar{\mu} \bar{\sigma}$. & 22,2 \\
\hline
\end{tabular}

Джерело: розроблено авторами.

За результатами оцінювання побудованих варіантів апроксимуючих залежностей Форма № 1 Форма № 4 за відповідності умови достатнього значення відносної похибки апроксимації підходять всі форми окрім Форми № 1, тому було прийнято рішення обрати остаточну альтернативну форму заданої залежності з меншою кількістю факторів. Таким чином, остаточна модель залежності максимальної аеродинамічної якості, яка в найкращий спосіб описує іiі залежність від обраних факторів, буде мати наступний вигляд:

$$
\bar{K}_{\max }=2,264-1,782 \cdot \bar{\mu}+0,239 \cdot \bar{\sigma}+0,422 \cdot \bar{\mu}^{2} .
$$

Межі надійної працездатності побудованої залежності (9) будуть визначатися діапазоном зміни значень факторів зі складу моделі, а саме:

- для нормованих значень факторів:

$$
\bar{\mu} \in[0,69 ; 2,19] ; \bar{\sigma} \in[0,68 ; 1,44] ;
$$

- для ненормованих значень факторів:

$$
\mu \in[0,26 ; 0,83] ; \sigma \in[164,1 ; 346,5] \frac{\kappa 2}{M^{2}} .
$$

Максимальна відносна похибка даної моделі на базовій вибірці дорівнює 22,8 \% - у бік заниження розрахункових даних, та 20,5\% - у бік завищення. Середня квадратична похибка на базовій вибірці складає 0,0403 .

Наступними факторами в існуючій кваліметричній моделі [14], для яких доцільно побудувати допоміжну модель, $є$ швидкість відриву $V_{\text {відр }}$, тобто мінімальна швидкість безпечного відділення літака від злітної смуги, та посадочна швидкість (швидкість літака в момент торкання основними його опорними пристроями поверхні злітної смуги на посадці). Вони визначаються відомими з теорії динаміки польоту літака виразами:

$$
\begin{gathered}
V_{\text {вidp }}=\sqrt{\frac{2 \sigma\left(1-\mu \sin \alpha_{P}\right)}{C_{y_{a} \text { вidp }} \cdot \rho}} ; \\
V_{\text {noc }}=\sqrt{\frac{2 m_{\text {noc }} \cdot g}{C_{y_{a} \text { noc }} \cdot \rho \cdot S}},
\end{gathered}
$$

де $C_{y_{a} \text { відр }}$ - коефіцієнт піднімальної сили під час відриву літака; $C_{y_{a} \text { пос }}-$ коефіцієнт піднімальної 
сили під час посадки літака; $\sigma$ - питоме навантаження на крило; $\mu$ - тягоозброєність; $\alpha_{P}-$ кут між вектором тяги і горизонтальною площиною.

Аналіз виразу (10) показує, що на значення швидкості відриву впливає, окрім значення коефіцієнту піднімальної сили літака у злітній конфігурації крила, питоме навантаження на крило та тягоозброєність. Також 3 аналізу виразу (11) слідує, що на значення посадочної швидкості впливають посадочна маса літака та площа крила. Але, оскільки посадочна маса літака $m_{n o c}$ відрізняється від його злітної маси $m_{3 л}$ лише у різній кількості палива в літаку в момент зльоту та в момент посадки, то можна припустити, що при побудові допоміжної моделі посадочну масу літака та площу крила можна замінити на параметр питомого навантаження на крило $\sigma=\frac{m_{3 л}}{S} \approx \frac{a \cdot m_{n о c}}{S}$, де $a-$ деякий невідомий коефіцієнт, що враховує різницю посадкової та злітної маси. Також, враховуючи те, що значення максимальної аеродинамічної якості характеризує дальність планерування літака, то відповідно при збільшенні дальності планерування літак зможе заходити на посадку $з$ меншою швидкістю. А значить, можна зробити висновок, що параметр посадочної швидкості залежить ще й від значення максимальної аеродинамічної якості. Оскільки з попереднього аналізу залежності максимальної аеродинамічної якості вже відомо, що максимальна аеродинамічна якість залежить від тягоозброєності літака $\mu$ та питомого навантаження на крило, то в якості початкового фактору можна використати параметр максимальної аеродинамічної якості, або впливаючи на цей параметр значення тягоозброєності та питомого навантаження на крило. Також з теорії динаміки польоту літака відомі вирази для визначення довжини розбігу та пробігу літака, які мають вид, відповідно:

$$
\begin{gathered}
L_{\text {розб }}=\frac{V_{\text {вiдp }}^{2}}{2 j_{x_{a} c e p}} \\
L_{\text {проб }}=-\frac{V_{n o c}^{2}}{2 j_{x_{a} c e p}},
\end{gathered}
$$

де $j_{x_{a} \text { сер }}-$ середнє прискорення літака;

$L_{\text {розб }}-$ довжина розбігу;

$L_{\text {проб }}$ - довжина пробігу.

3 аналізу рівнянь (12) та (13) можна зробити висновок, що параметри швидкостей відриву та посадки можуть бути наближено описаними залежністю від значень довжин розбігу та пробігу літака.

Таким чином значення вищевказаних швидкостей можна представити як деякі функції від зазначених вище ТTХ літака:

$$
V_{\text {вiдp }}=f\left(\sigma ; \mu ; L_{\text {розб }}\right)
$$

та

$$
V_{\text {пос }}=f\left(\sigma ; L_{\text {проб }} ; \mu\right)
$$

Також з аналізу виразів (10)-(12) та (13) простежується тенденції впливу вхідних параметрів на результуючі параметри. При збільшенні значення одних факторів результуючий параметр в основному збільшується, а при збільшенні інших - зменшується. Тому для вірного відображення допоміжними моделями відомих тенденцій зміни вищеназваних швидкостей при зміні значень обраних факторів, часткові похідні при побудові відповідних апроксимуючих залежностей повинні виглядати наступним чином:

$$
\begin{array}{lll}
\frac{\partial V_{\text {відp }}}{\partial \sigma}>0 ; & \frac{\partial V_{\text {відp }}}{\partial L_{\text {розб }}}>0 ; & \frac{\partial V_{\text {відp }}}{\partial \mu}<0 ; \\
\frac{\partial V_{\text {nос }}}{\partial \sigma}>0 ; & \frac{\partial V_{\text {пос }}}{\partial L_{\text {проб }}}>0 ; & \frac{\partial V_{\text {nос }}}{\partial \mu}<0 .
\end{array}
$$

Наближені моделі невідомих функціональних зв'язків (14) та (15) встановлюються в аналогічний спосіб, як і у випадку побудови допоміжної моделі максимальної аеродинамічної якості, що вже був вище описаний, тобто шляхом обробки наявної статистичної інформації про вже відомі значення параметрів реалізованих в світовій практиці НБЛ та їх TTX зі складу обраних факторних просторів за допомогою МГУА.

Дані значень ТТХ типів літаків, що увійшли до факторного простору невідомих залежностей (14) та (15) та розрахункові значення шуканих параметрів наведені в табл. 5-6.

Таблиця 5

Факторний простір початкових даних для визначення швидкості відриву

та розрахункові значення швидкості відриву

\begin{tabular}{|c|c|c|c|c|c|}
\hline Тип літака & $\begin{array}{c}\text { Питоме наванта- } \\
\text { ження на крило }\end{array}$ & Тягообброєність & $\begin{array}{c}\text { Довжина } \\
\text { розбігу }\end{array}$ & $\begin{array}{c}\text { Швидкість } \\
\text { відриву }\end{array}$ & $\begin{array}{c}\text { Швидкість відриву } \\
\text { розрахункова }\end{array}$ \\
\hline 1 & 2 & 3 & 4 & 5 & 6 \\
\hline CM-170 “Magister” & 0,68 & 0,74 & 1,28 & 1,05 & 0,91 \\
\hline “Gnat” T.Mk-1 & 0,89 & 1,44 & 1,29 & 0,99 & 0,98 \\
\hline MB-326G (GB) & 0,95 & 0,92 & 1,25 & 0,97 & 1,01 \\
\hline
\end{tabular}


Закінчення табл. 5

\begin{tabular}{|c|c|c|c|c|c|}
\hline 1 & 2 & 3 & 4 & 5 & 6 \\
\hline L-29 "Delfin” & 0,69 & 0,72 & 1,08 & 0,87 & 0,87 \\
\hline CL-41 (CT-114) “Tutor" & 0,68 & 1,05 & 1,08 & 0,79 & 0,86 \\
\hline T-38A (B) "Talon" & 1,38 & 1,77 & 1,47 & 1,50 & 1,27 \\
\hline $\mathrm{T}-2 \mathrm{~B}(\mathrm{C})$ & 1,00 & 1,28 & 0,98 & 0,89 & 0,96 \\
\hline G-2A "Galeb" & 0,80 & 0,78 & 1,29 & 1,07 & 0,96 \\
\hline Saab-105 (Sk-60) & 1,03 & 1,09 & 1,20 & 0,88 & 1,03 \\
\hline BAC-167 "Strikemaster" & 1,00 & 0,86 & 1,02 & 0,94 & 0,98 \\
\hline L-39 “Albatros" & 1,00 & 1,00 & 1,00 & 1,00 & 0,98 \\
\hline "Hawk" T Mk.1 & 1,25 & 1,23 & 1,02 & 1,03 & 1,11 \\
\hline "Alpha Jet" & 1,19 & 1,42 & 0,73 & 1,16 & 1,00 \\
\hline MB-339A & 0,95 & 1,09 & 1,40 & 0,97 & 1,03 \\
\hline HJT-16 “Kiran-II” Mk.2 & 0,93 & 1,18 & 0,98 & 0,86 & 0,93 \\
\hline C.101 "Aviojet" & 1,01 & 0,91 & 0,88 & 1,12 & 0,96 \\
\hline G-4 (M) "Super Galeb" & 1,00 & 1,02 & 1,12 & 1,07 & 1,00 \\
\hline AT-3A (B) "Tsu Chiang" & 1,00 & 1,58 & 0,88 & 1,10 & 0,94 \\
\hline S.221 & 0,91 & 1,09 & 0,78 & 0,82 & 0,88 \\
\hline IA-63 "Pampa" & 1,01 & 1,10 & 0,83 & 1,02 & 0,94 \\
\hline T-4 & 1,13 & 1,53 & 1,29 & 0,99 & 1,09 \\
\hline L-59 (L-39MS) & 1,19 & 1,07 & 1,02 & 1,10 & 1,08 \\
\hline "Hawk-100" & 1,28 & 1,36 & 1,18 & 1,03 & 1,16 \\
\hline T-45 "Goshawk" & 1,44 & 1,21 & 0,75 & 1,18 & 1,17 \\
\hline TA-4J Skyhawk & 1,27 & 1,38 & 1,63 & 1,37 & 1,24 \\
\hline T-50 "Golden Eagle" & 1,39 & 2,39 & 1,00 & 1,05 & 1,16 \\
\hline M.346 "Master" & 1,21 & 2,19 & 0,63 & 1,11 & 0,97 \\
\hline Yak-130 & 1,20 & 1,97 & 0,78 & 1,11 & 1,01 \\
\hline JL-15 (L-15) & 1,46 & 2,84 & 0,59 & 1,05 & 1,11 \\
\hline
\end{tabular}

Джерело: розроблено авторами за даними [2-3; 21-22].

Таблиця 6

Факторний простір початкових даних для визначення посадкової швидкості та розрахункові значення посадкової швидкості

\begin{tabular}{|c|c|c|c|c|c|}
\hline Тип літака & $\begin{array}{c}\text { Питоме } \\
\text { навантаження } \\
\text { на крило }\end{array}$ & $\begin{array}{c}\text { Довжина } \\
\text { пробігу }\end{array}$ & Тягоозброєність & $\begin{array}{c}\text { Посадкова } \\
\text { швидкість }\end{array}$ & $\begin{array}{c}\text { Посадкова } \\
\text { швидкість } \\
\text { розрахункова }\end{array}$ \\
\hline 1 & 2 & 3 & 4 & 5 & 6 \\
\hline T-33A (B) & 1,09 & 0,97 & 1,13 & 1,22 & 1,08 \\
\hline P-84 “Jet Provost” T.Mk-4 & 0,72 & 0,85 & 0,86 & 0,75 & 0,83 \\
\hline "Gnat” T.Mk-1 & 0,89 & 1,29 & 1,44 & 1,03 & 0,91 \\
\hline MB-326G (GB) & 0,95 & 1,21 & 0,92 & 1,01 & 1,04 \\
\hline L-29 “Delfin” & 0,69 & 0,71 & 0,72 & 0,89 & 0,80 \\
\hline TS-11 “Iskra” & 0,90 & 1,05 & 0,69 & 0,86 & 1,02 \\
\hline CL-41 (CT-114) “Tutor” & 0,68 & 0,97 & 1,05 & 0,81 & 0,77 \\
\hline T-38A (B) “Talon” & 1,38 & 1,37 & 1,77 & 1,33 & 1,26 \\
\hline T-2B (C) & 1,00 & 0,97 & 1,28 & 0,87 & 0,99 \\
\hline G-2A “Galeb” & 0,80 & 0,97 & 0,78 & 1,10 & 0,91 \\
\hline Saab-105 (Sk-60) & 1,03 & 0,89 & 1,09 & 0,92 & 1,04 \\
\hline BAC-167 “Strikemaster” & 1,00 & 1,03 & 0,86 & 0,97 & 1,07 \\
\hline
\end{tabular}


Закінчення табл. 6

\begin{tabular}{|c|c|c|c|c|c|}
\hline 1 & 2 & 3 & 4 & 5 & 6 \\
\hline L-39 "Albatros" & 1,00 & 1,00 & 1,00 & 1,00 & 1,04 \\
\hline "Hawk" T Mk.1 & 1,25 & 0,79 & 1,23 & 1,33 & 1,18 \\
\hline "Alpha Jet" & 1,19 & 0,81 & 1,42 & 1,06 & 1,10 \\
\hline MB-339A & 0,95 & 0,67 & 1,09 & 1,05 & 0,95 \\
\hline HJT-16 “Kiran-II” Mk.2 & 0,93 & 1,05 & 1,18 & 0,89 & 0,96 \\
\hline C.101 "Aviojet" & 1,01 & 0,87 & 0,91 & 0,98 & 1,05 \\
\hline G-4 (M) "Super Galeb" & 1,00 & 1,11 & 1,02 & 1,10 & 1,05 \\
\hline AT-3A (B) "Tsu Chiang" & 1,00 & 1,08 & 1,58 & 1,13 & 0,95 \\
\hline S.221 & 0,91 & 0,58 & 1,09 & 0,84 & 0,90 \\
\hline IA-63 "Pampa" & 1,01 & 0,74 & 1,10 & 1,23 & 1,00 \\
\hline $\mathrm{T}-4$ & 1,13 & 1,14 & 1,53 & 1,02 & 1,07 \\
\hline L-59 (L-39MS) & 1,19 & 1,05 & 1,07 & 1,13 & 1,19 \\
\hline "Hawk-100" & 1,28 & 0,94 & 1,36 & 1,33 & 1,20 \\
\hline T-45 "Goshawk" & 1,44 & 0,73 & 1,21 & 1,29 & 1,33 \\
\hline TA-4J Skyhawk & 1,27 & 1,05 & 1,38 & 1,33 & 1,19 \\
\hline T-50 "Golden Eagle" & 1,39 & 1,02 & 2,39 & 1,06 & 1,11 \\
\hline M.346 "Master" & 1,21 & 0,92 & 2,19 & 0,92 & 0,99 \\
\hline Yak-130 & 1,20 & 1,05 & 1,97 & 1,06 & 1,04 \\
\hline JL-15 (L-15) & 1,46 & 0,81 & 2,84 & 1,06 & 1,07 \\
\hline
\end{tabular}

Джерело: розроблено авторами за даними [2-3; 21-22].

Для побудови допоміжної апроксимуючої моделі кожної із залежностей (14) та (15) було сфор- мовано по сім альтернативних їх форм, які наведені табл. 7 та табл. 8, відповідно.

Альтернативні форми апроксимуючих моделей для визначення швидкості відриву

\begin{tabular}{|c|c|}
\hline $\begin{array}{l}\text { Номер форми та } \\
\text { кількість факторів }\end{array}$ & Форма запису моделі \\
\hline форма № 1 - (3 фактора) & $\bar{V}_{\text {вiдp }}=a_{0}+a_{\sigma} \cdot \bar{\sigma}+a_{\mu} \cdot \bar{\mu}+a_{L_{\text {розб }}} \cdot \bar{L}_{\text {розб }}$ \\
\hline форма № 2 - (4 факторів) & $\bar{V}_{\text {вiдp }}=a_{0}+a_{\sigma} \cdot \bar{\sigma}+a_{\mu} \cdot \bar{\mu}+a_{L_{\text {розб }}} \cdot \bar{L}_{\text {розб }}+a_{2 \sigma} \cdot \bar{\sigma}^{2}$ \\
\hline форма № 3 - (5 факторів $)$ & $\bar{V}_{\text {вiдp }}=a_{0}+a_{\sigma} \cdot \bar{\sigma}+a_{\mu} \cdot \bar{\mu}+a_{L_{\text {розб }}} \cdot \bar{L}_{\text {розб }}+a_{2 \sigma} \cdot \bar{\sigma}^{2}+a_{2 \mu} \cdot \bar{\mu}^{2}$ \\
\hline форма № 4 -(6 факторів) & 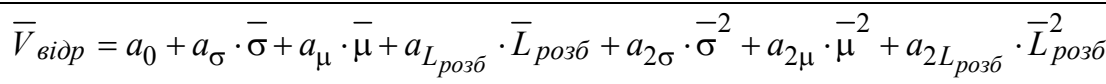 \\
\hline форма № 5 - (7 факторів) & 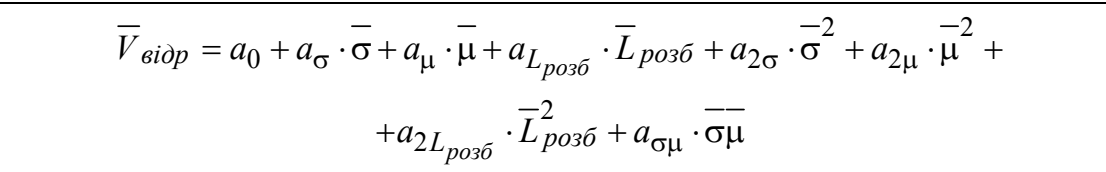 \\
\hline орма № 6 - (8 факторів) & 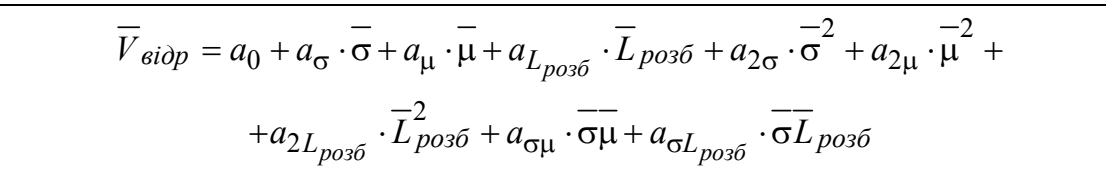 \\
\hline форма № 7 - (9 факторів) & 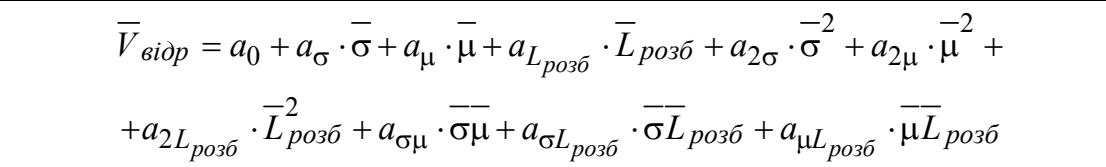 \\
\hline
\end{tabular}

Джерело: розроблено авторами. 
Альтернативні форми залежності для визначення посадкової швидкості

\begin{tabular}{|c|c|}
\hline $\begin{array}{l}\text { Номер форми } \\
\text { та кількість факторів }\end{array}$ & Форма запису моделі \\
\hline форма № 1 - (3 фактора) & $\bar{V}_{n о c}=a_{0}+a_{\sigma} \cdot \bar{\sigma}+a_{L_{\text {розб }}} \cdot \bar{L}_{\text {розб }}+a_{\mu} \cdot \bar{\mu}$ \\
\hline форма № 2 - (4 факторів) & $\bar{V}_{n o c}=a_{0}+a_{\sigma} \cdot \bar{\sigma}+a_{L_{\text {розб }}} \cdot \bar{L}_{\text {розб }}+a_{\mu} \cdot \bar{\mu}+a_{2 \sigma} \cdot \bar{\sigma}^{2}$ \\
\hline форма № 3 - (5 факторів) & $\bar{V}_{n o c}=a_{0}+a_{\sigma} \cdot \bar{\sigma}+a_{L_{\text {розб }}} \cdot \bar{L}_{\text {розб }}+a_{\mu} \cdot \bar{\mu}+a_{2 \sigma} \cdot \bar{\sigma}^{2}+a_{2 L_{\text {розб }}} \cdot \bar{L}_{\text {розб }}^{2}$ \\
\hline форма № 4 -(6 факторів) & $\bar{V}_{n о c}=a_{0}+a_{\sigma} \cdot \bar{\sigma}+a_{L_{\text {розб }}} \cdot \bar{L}_{\text {розб }}+a_{\mu} \cdot \bar{\mu}+a_{2 \sigma} \cdot \bar{\sigma}^{2}+a_{2 L_{\text {розб }}} \cdot \bar{L}_{\text {розб }}^{2}+a_{2 \mu} \cdot \bar{\mu}^{2}$ \\
\hline форма № 5 - (7 факторів) & $\begin{array}{c}\bar{V}_{n о с}=a_{0}+a_{\sigma} \cdot \bar{\sigma}+a_{L_{\text {розб }}} \cdot \bar{L}_{\text {розб }}+a_{\mu} \cdot \bar{\mu}+a_{2 \sigma} \cdot \bar{\sigma}^{2}+ \\
\quad+a_{2 L_{\text {розб }}} \cdot \bar{L}_{\text {розб }}^{2}+a_{2 \mu} \cdot \bar{\mu}^{2}+a_{\sigma L_{\text {розб }}} \cdot \bar{\sigma}_{\text {розб }}\end{array}$ \\
\hline форма № 6 - (8 факторів) & $\begin{array}{c}\bar{V}_{n o c}=a_{0}+a_{\sigma} \cdot \bar{\sigma}+a_{L_{\text {розб }}} \cdot \bar{L}_{\text {розб }}+a_{\mu} \cdot \bar{\mu}+a_{2 \sigma} \cdot \bar{\sigma}^{2}+a_{2 L_{\text {розб }}} \cdot \bar{L}_{\text {розб }}^{2}+ \\
+a_{2 \mu} \cdot \bar{\mu}^{2}+a_{\sigma L_{\text {розб }}} \cdot \bar{\sigma} \bar{L}_{\text {розб }}+a_{\sigma \mu} \cdot \overline{\sigma \mu}\end{array}$ \\
\hline форма № 7 - (9 факторів) & $\begin{aligned} \bar{V}_{\text {nос }}= & a_{0}+a_{\sigma} \cdot \bar{\sigma}+a_{L_{\text {розб }}} \cdot \bar{L}_{\text {розб }}+a_{\mu} \cdot \bar{\mu}+a_{2 \sigma} \cdot \bar{\sigma}^{2}+a_{2 L_{\text {розб }}} \cdot \bar{L}_{\text {розб }}^{2}+ \\
& +a_{2 \mu} \cdot \bar{\mu}^{2}+a_{\sigma L_{\text {розб }}} \cdot \bar{\sigma} \bar{L}_{\text {розб }}+a_{\sigma \mu} \cdot \overline{\sigma \mu}+a_{L_{\text {розб }} \mu} \cdot \bar{L}_{\text {розб }} \bar{\mu}\end{aligned}$ \\
\hline
\end{tabular}

Джерело: розроблено авторами.

В даних альтернативних формах апроксимуючих залежностей невідомі значення вільного члену позначені як $a_{0}$, а невідомих коефіцієнтів при відповідних факторах - через $a_{\sigma}, \ldots a_{L_{\text {розб }}}$,

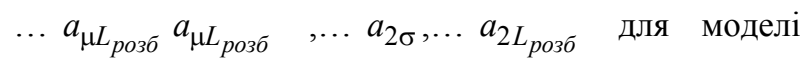
визначення швидкості відриву, та через $\ldots a_{\mu} a_{\mu}$, $\ldots a_{2 \mu} a_{2 \mu}, \ldots a_{L_{n р о б} \mu} a_{L_{n р о б} \mu}$ для моделі визначення посадкової швидкості.

Кожна 3 приведених форм перевірялась на дотримання умов точності апроксимації та відповід- ність поведінки кожної з швидкостей при зміні факторів відповідної моделі. Також, у випадку відповідності усім поставленим умовам декількох моделей приймалось рішення щодо обрання моделі 3 меншою кількістю початкових факторів для спрощення подальших розрахунків.

За допомогою методу найменших квадратів визначено невідомі значення коефіцієнтів при відповідних факторах та для кожної альтернативної форми було розраховане значення відносної похибки апроксимації. Результати даних розрахунків наведені в табл. 9-10.

Таблиця 9

Альтернативні форми апроксимуючих моделей для невідомої залежності (14) з відповідними значеннями відносної похибки апроксимації

\begin{tabular}{|c|c|c|}
\hline № форми & Форма запису моделі & $\delta_{\max }$ \\
\hline 1 & 2 & 3 \\
\hline форма № 1 & $\bar{V}_{\text {вiдp }}=0,3+0,51 \cdot \bar{\sigma}-0,02 \cdot \bar{\mu}+0,22 \cdot \bar{L}_{р о з б}$ & 20 \\
\hline форма № 2 & $\bar{V}_{\text {вiдp }}=0,52+0,07 \cdot \bar{\sigma}-0,03 \cdot \bar{\mu}+0,21 \cdot \bar{L}_{\text {розб }}+0,21 \cdot \bar{\sigma}^{2}$ & 17 \\
\hline форма № 3 & $\bar{V}_{\text {вiдp }}=0,61-0,26 \cdot \bar{\sigma}+0,13 \cdot \bar{\mu}+0,2 \cdot \bar{L}_{\text {розб }}+0,36 \cdot \bar{\sigma}^{2}-0,05 \cdot \bar{\mu}^{2}$ & 18 \\
\hline форма № 4 & $\bar{V}_{\text {відр }}=1,61-0,17 \cdot \bar{\sigma}+0,12 \cdot \bar{\mu}-1,64 \cdot \bar{L}_{\text {розб }}+0,27 \cdot \bar{\sigma}^{2}-0,06 \cdot \bar{\mu}^{2}+0,83 \cdot \bar{L}_{\text {розб }}^{2}$ & 18 \\
\hline форма № 5 & $\begin{array}{c}\bar{V}_{\text {вidp }}=1,88-0,16 \cdot \bar{\sigma}-0,18 \cdot \bar{\mu}-1,78 \cdot \bar{L}_{\text {розб }}-0,18 \cdot \bar{\sigma}^{2}- \\
-0,27 \cdot \bar{\mu}^{2}+0,87 \cdot \bar{L}_{\text {розб }}^{2}+0,79 \cdot \overline{\sigma \mu}\end{array}$ & 21 \\
\hline
\end{tabular}


Закінчення табл. 9

\begin{tabular}{|c|c|c|}
\hline 1 & 2 & 3 \\
\hline форма № 6 & $\bar{V}_{\text {відр }}=1,99-0,28 \cdot \bar{\sigma}-0,17 \cdot \bar{\mu}-1,86 \cdot \bar{L}_{\text {розб }}-0,13 \cdot \bar{\sigma}^{2}-$ & 21 \\
\hline \multirow{2}{*}{ форма № 7 } & $-0,24 \cdot \bar{\mu}^{2}+0,86 \cdot \bar{L}_{\text {розб}}^{2}+0,72 \cdot \bar{\sigma} \bar{\mu}+0,08 \cdot \bar{\sigma} \bar{L}_{\text {розб }}$ & \\
& $\bar{V}_{\text {вiдp }}=2,07+0,34 \cdot \bar{\sigma}-0,55 \cdot \bar{\mu}-2,15 \cdot \bar{L}_{\text {розб }}-0,27 \cdot \bar{\sigma}-$ & 22 \\
\hline
\end{tabular}

Джерело: розроблено авторами.

Альтернативні форми апроксимуючих моделей для невідомої залежності (15)

з відповідними значеннями відносної похибки апроксимації

\begin{tabular}{|c|c|c|}
\hline № форми & Форма запису моделі & $\delta_{\max }$ \\
\hline форма № 1 & $\bar{V}_{n о c}=0,3+0,81 \cdot \bar{\sigma}+0,11 \cdot \bar{L}_{\text {розб }}-0,18 \cdot \bar{\mu}$ & 19 \\
\hline форма № 2 & $\bar{V}_{\text {пос }}=0,43+0,58 \cdot \bar{\sigma}+0,12 \cdot \bar{L}_{\text {розб }}-0,18 \cdot \bar{\mu}+0,11 \cdot \bar{\sigma}^{2}$ & 21 \\
\hline форма № 3 & $\bar{V}_{n o c}=0,76+0,72 \cdot \bar{\sigma}-0,75 \cdot \bar{L}_{\text {розб }}-0,18 \cdot \bar{\mu}+0,04 \cdot \bar{\sigma}^{2}+0,44 \cdot \bar{L}_{\text {розб }}^{2}$ & 20 \\
\hline форма № 4 & $\bar{V}_{\text {пос }}=0,73+0,02 \cdot \bar{\sigma}-0,41 \cdot \bar{L}_{\text {розб }}+0,2 \cdot \bar{\mu}+0,35 \cdot \bar{\sigma}^{2}+0,25 \cdot \bar{L}_{\text {розб }}^{2}-0,11 \cdot \bar{\mu}^{2}$ & 19 \\
\hline форма №5 & $\begin{aligned} \bar{V}_{\text {nос }}= & 0,72+0,04 \cdot \bar{\sigma}-0,41 \cdot \bar{L}_{\text {розб }}+0,2 \cdot \bar{\mu}+0,35 \cdot \bar{\sigma}^{2}+ \\
& +0,26 \cdot \bar{L}_{\text {розб }}^{2}-0,11 \cdot \bar{\mu}^{2}-0,02 \cdot \bar{\sigma} \bar{L}_{\text {розб }}\end{aligned}$ & 19 \\
\hline форма № 6 & $\begin{array}{l}\bar{V}_{\text {nос }}=0,45+0,55 \cdot \bar{\sigma}+0,06 \cdot \bar{L}_{\text {розб }}-0,18 \cdot \bar{\mu}-0,22 \cdot \bar{\sigma}^{2}+ \\
\quad+0,33 \cdot \bar{L}_{\text {розб }}^{2}-0,37 \cdot \bar{\mu}^{2}-0,6 \cdot \bar{\sigma} \bar{L}_{\text {розб }}+1,005 \cdot \overline{\sigma \mu}\end{array}$ & 17 \\
\hline форма № 7 & $\begin{array}{c}\bar{V}_{\text {пос }}=0,42+0,9 \cdot \bar{\sigma}+0,11 \cdot \bar{L}_{\text {розб }}-0,44 \cdot \bar{\mu}-0,31 \cdot \bar{\sigma}^{2}+ \\
+0,3 \cdot \bar{L}_{\text {розб }}^{2}-0,36 \cdot \bar{\mu}^{2}-0,81 \cdot \bar{\sigma} \bar{L}_{\text {розб }}+1,05 \cdot \overline{\sigma \mu}+0,18 \cdot \bar{L}_{\text {розб }} \bar{\mu}\end{array}$ & 17 \\
\hline
\end{tabular}

Джерело: розроблено авторами.

Таким чином, 3 урахування дотримання всіх поставлених умов, а саме, по умові точності апроксимації та правильності поведінки впливу вхідних параметрів на результуючу ознаку, а також при умові меншої кількості початкових параметрів, для визначення швидкості відриву було обрано Форму № 2 (табл. 9), а для визначення посадочної швидкості - Форму № 1 (табл. 10). Побудовані допоміжні моделі залежності швидкості відриву та залежності посадкової швидкості від обраних факторів мають наступний вигляд, відповідно:

$$
\begin{gathered}
\bar{V}_{\text {відр }}=0,515+0,068 \cdot \bar{\sigma}-0,029 \cdot \bar{\mu}+ \\
+0,212 \cdot \bar{L}_{\text {розб }}+0,211 \cdot \bar{\sigma}^{2} ; \\
\bar{V}_{\text {пос }}=0,3+0,806 \cdot \bar{\sigma}+0,108 \cdot \bar{L}_{\text {проб }}-0,175 \cdot \bar{\mu}
\end{gathered}
$$

Межі надійної працездатності побудованих залежностей (17) та (18) будуть визначатися діапазоном зміни значень факторів зі складу моделі, а саме:

- для нормованих значень факторів:

$$
\begin{aligned}
\bar{\sigma} & \in[0,68 ; 1,46] ; \bar{\mu} \in[0,69 ; 2,84] ; \\
\bar{L}_{\text {розб }} & \in[0,59 ; 1,63] ; \bar{L}_{\text {проб }} \in[0,58 ; 1,37] ;
\end{aligned}
$$

- для ненормованих значень факторів:

$$
\begin{gathered}
\sigma \in[164,1 ; 352,4] \frac{\kappa 2}{M^{2}} ; \mu \in[0,26 ; 1,08] ; \\
L_{\text {розб }} \in[300 ; 830] \mu ; \quad L_{\text {проб }} \in[361 ; 850] \mu .
\end{gathered}
$$

Максимальна відносна похибка моделі визначення швидкості відриву на базовій вибірці (17) дорівнює $15,2 \%$ - у бік заниження розрахункових даних, та 16,8\% - у бік завищення. Середня квадратична похибка на базовій вибірці складає 0,083. Максимальна відносна похибка моделі (18) на базовій вибірці дорівнює $18,8 \%$ - у бік заниження розрахункових даних, та 19,2\% - у бік завищення. Середня квадратична похибка на базовій вибірці для даної моделі складає $0,087$.

Характеристики точності описання допоміжними моделями (17) та (18) вибірки наявного статистичного матеріалу, що відображує накопичений досвід ретроспективи розвитку реактивних НБЛ (НТЛ) на світовому рівні, дозволяють рекомендувати побудовані моделі для практичного застосування при формуванні початкових даних в удосконаленій методиці порівняльного оцінювання різних типів 
літаків даного класу. Побудовані допоміжні математичні моделі залежності із достатньою точністю дозволятимуть визначати ТТХ НБЛ (НТЛ) зі складу кваліметричних моделей з використанням доступної технічної інформації.

\section{Висновки}

Проведено аналіз існуючої методики порівняльного оцінювання навчально-бойових літаків за ступенем пристосованості до навчальної льотної підготовки курсантів та визначено напрями іiі подальшого удосконалення.

Запропоновано можливий шлях удосконалення даної методики на основі побудови допоміжних апроксимуючих моделей залежності факторів існуючих кваліметричних моделей, визначення значень відповідних ТTX яких для сучасних та перспективних літаків пов'язано із значними труднощами. Проаналізовано наявні джерела технічної інформації та інформації, яку виробник надає при оформленні технічної пропозиції, внаслідок чого сформовано перелік ТТХ, які можуть бути включені до оновленого факторного простору початкових даних удосконаленої кваліметричної моделі.

Побудовано допоміжні математичні моделі визначення часткових показників літака та здійснено оцінювання точності апроксимації ними наявного статистичного матеріалу щодо ретроспективи розвитку реактивних навчально-бойових (навчальнотренувальних) літаків.

Отримані оцінки точності апроксимації та вірне відображення тенденцій поведінки факторів при зміні значень параметрів моделі дозволяє рекомендувати побудовані допоміжні моделі для практичного використання.

В подальшому планується побудувати допоміжні математичні моделі решти часткових показників для удосконалення існуючих кваліметричних моделей навчальних властивостей реактивних навчальнобойових (навчально-тренувальних) літаків на основі оновлення їх факторного простору.

\section{Список літератури}

1. Візія Повітряних Сил 2035. - Вінниця: Командування Повітряних Сил Збройних Сил України. - 2020. - 42 с.

2. Нор П.І. Реактивні навчально-тренувальні літаки: покоління; технічні характеристики; порівняльна оцінка / П.І. Нор, Л.Ю. Новосад. - К.: Фітон, 2012. - 160 с.

3. Нор П.И. Анализ развития учебно-тренировочных самолетов с турбореактивными двигателями / П.И. Нор // Наука і техніка Повітряних Сил Збройних Сил України. - 2010. - № 1(3). - С. 11-19.

4. Нор П.І. Методика оцінки технічного рівня зразків озброєння та військової техніки / П.І. Нор, О.М. Горський, А.Г. Павленко // Збірник наукових праць Центрального науково-дослідного інституту озброєння та військової техніки Збройних Сил України. - 2012. - № 34. - С. 188-194.

5. Основні технічні показники оцінки ефективності парків озброєння та військової техніки Збройних Сил / В.А. Єфіменко, П.І. Нор, А.Ю. Гупало, О.В. Кучурін // Збірник наукових праць Центрального науково-дослідного інституту озброєння та військової техніки Збройних Сил України. - 2012. - № 34. - С. 87-98.

6. Методика оцінки технічного рівня систем озброєння озброєння збройних сил / В.А. Єфіменко, А.І. Крикуненко, П.І. Нор, О.Д. Мельник // Збірник наукових праць Центрального науково-дослідного інституту озброєння та військової техніки Збройних Сил України. - 2010. - № 15(37). - С. 131-146.

7. Кондратюк В.К. Методологія оцінки технічного рівня зразків ОВТ на стадії розробки ТТЗ / В.К. Кондратюк, О.Н. Серебровський, В.О. Смірнов // Збірник наукових праць Центрального науково-дослідного інституту озброєння та військової техніки Збройних Сил України. - 1998. - № 1. - С. 58-68.

8. Самков О.В. До питання порівняльної оцінки військових літаків / О.В. Самков, О.С. Мавренков // Збірник наукових праць Київського інституту Військово-Повітряних Сил. - 1999. - № 6. - С. 135-140.

9. Сжов С.О. Експрес-метод інтегральної оцінки якості однотипних зразків авіаційної техніки / С.О. Сжов // Збірник наукових праць наукового центру Військово-Повітряних Сил. - 1998. - № 2. - С. 128-133.

10. Сланський О.В. Оцінка досконалості авіаційного навчально-бойового комплексу на попередніх етапах його проектування або подальшої модернізації / О.В. Сланський // Системи озброєння і військова техніка. - 2014. - № 3. C. 33-36.

11. Логинов В.В. Методологические основы формирования параметрического облика силовой установки перспективного учебно-боевого самолета: монографія / В.В. Логинов, А.В. Еланский, И.Ф. Кравченко. - Х.: ХУВС им. Ивана Кожедуба, 2016. - 294 с.

12. Алімпієв А.М. Методичний підхід до порівняльного оцінювання варіантів навчально-бойового літака для підготовки курсантів / А.М. Алімпієв, В.П. Срошенко, О.Б. Леонтьєв // Тези доповідей V міжнародної науково-практичної конференції "Проблеми координації воєнно-технічної та оборонно-промислової політики в Україні. Перспективи розвитку озброєння та військової техніки”. - Київ, 11-12 жовтня 2017 р. - С. 216-217.

13. Алімпієв А.М. Порівняльне оцінювання сучасних реактивних навчально-бойових літаків за ступенем пристосованості до задач базової льотної підготовки курсантів // А.М. Алімпієв, В.П. Єрошенко, О.Б. Леонтьєв // Тези доповідей XIV наукової конференції Харківського національного університету Повітряних Сил імені Івана Кожедуба "Новітні технології - для захисту повітряного простору”. - Харків, 11-12 квітня 2018 р. - С. 72. 
14. Кваліметричні моделі ступеню придатності навчально-бойового літака до використання в базовій навчальній льотній підготовці курсантів / В.П. Єрошенко, О.Б. Леонтьєв, М.В. Науменко, І.Б. Ковтонюк // Наука і техніка Повітряних Сил Збройних Сил України. - 2019. - № 2(35). - С. 79-87. https://doi.org/10.30748/nitps.2019.35.10.

15. Обгрунтування вибору факторного простору для побудови кваліметричної моделі навчально-бойового літака на основі аналізу курсу навчальної льотної підготовки курсантів / А.М. Алімпієв, В.П. Єрошенко, І.Б. Ковтонюк, О.Б. Леонтьєв // Наука і техніка Повітряних Сил Збройних Сил України. - 2016. - № 3(24). - С. 54-59.

16. Алімпієв А.М. Аналіз та уточнення факторного простору для побудови кваліметричної моделі навчальнобойового літака / А.М. Алімпієв, В.П. Єрошенко, І.Б. Ковтонюк // Системи озброєння і військова техніка. - 2017. № 2(50). - С. 7-9.

17. Результати оцінювання вагомості окремих тактико-технічних показників навчально-бойових літаків методом експертного оцінювання / А.М. Алімпієв, О.Б. Леонтьєв, В.П. Єрошенко, І.Б. Ковтонюк, М.В. Науменко // Системи озброєння і військова техніка. - 2019. - № 1(57). - С. 48-55. https://doi.org/10.30748/soivt.2019.57.07.

18. Особенности проектирования легких боевых и учебно-тренировочных самолетов / А.Н. Акимов, В.В. Ворбьев, О.Ф. Демченко и др.; под. ред. Н.Н. Долженкова и В.А. Подобедова. - М.: Машиностроение, Машиностроение-Полет, 2005. $-368 \mathrm{c}$.

19. Григорьев Н.Г. Основы аэродинамики и динамики полета / Н.Г. Григорьев. - М.: Машиностроение, 1995. - 400 с.

20. Семенчин В.А. Аэродинамика и динамика полета / В.А. Семенчин, В.А. Захаренко, В.В. Чмовж. - Х.: ХАИ, 2003. $-381 \mathrm{c}$.

21. Послевоенная вспомогательная авиация [Електронний ресурс]. - Режим доступу: http://www.airwar.ru/ other.html.

22. Современная вспомогательная авиация [Електронний ресурс]. - Режим доступу: http://www.airwar.ru/ othernow.html.

Надійшла до редколегії 31.03.2021

Схвалена до друку 12.05.2021

\section{Відомості про авторів:}

Леонтьсв Олексій Борисович доктор технічних наук професор головний науковий співробітник Харківського національного університету Повітряних Сил ім. І. Кожедуба, Харків, Україна https://orcid.org/0000-0003-4003-7759

\section{Бердочник Дмитро Вадимович} ад'юнкт

Харківського національного університету

Повітряних Сил ім. І. Кожедуба,

Харків, Україна

https://orcid.org/0000-0003-3185-0342

\section{Бердочник Алла Дмитрівна}

молодший науковий співробітник

Харківського національного університету

Повітряних Сил ім. І. Кожедуба,

Харків, Україна

https://orcid.org/0000-0001-9707-998X

\section{Information about the authors:}

Oleksii Leontiev

Doctor of Technical Sciences Professor

Chief Research

of Ivan Kozhedub Kharkiv

National Air Force University,

Kharkiv, Ukraine

https://orcid.org/0000-0003-4003-7759

\author{
Dmitro Berdochnik \\ Doctoral Student \\ of Ivan Kozhedub Kharkiv \\ National Air Force University, \\ Kharkiv, Ukraine \\ https://orcid.org/0000-0003-3185-0342
}

\author{
Alla Berdochnik \\ Junior Research Associate \\ of Ivan Kozhedub Kharkiv National \\ Air Force University, \\ Kharkiv, Ukraine \\ https://orcid.org/0000-0001-9707-998X
}

\title{
УСОВЕРШЕНСТВОВАНИЕ МЕТОДИКИ СРАВНИТЕЛЬНОГО ОЦЕНИВАНИЯ РАЗНЫХ ТИПОВ РЕАКТИВНЫХ УЧЕБНО-ТРЕНИРОВОЧНЫХ (УЧЕБНО-БОЕВЫХ) САМОЛЕТОВ
}

\author{
А.Б. Леонтьєв, Д.В. Бердочник, А.Д. Бердочник
}

Проведен анализ существующих методических подходов для сравнительного оценивания реактивных учебнобоевых (учебно-тренировочных) самолетов и проанализированы недостатки при практическом использовании каждого из методического подхода. Предложено усовершенствование существующей методики определения квалиметрического значения степени приспособленности к базовой летной подготовке курсантов путем замены входных факторов начального пространства методики на вспомогательные интерполяционные модели, в начальные данные которых вошли характеристики самолета, значения которых являются доступными из имеющихся источников научно-технической информации. Проведенная оченка полученных вспомогательных моделей по условиям точности аппроксимации и правильности поведения факторов при изменении значений входных параметров.

Ключевые слова: сравнительное оченивание, учебно-тренировочные (учебно-боевые) самолеты, факторное пространство, квалиметрическая модель, вспомогательная интерполяиионая модель. 


\title{
IMPROVEMENT OF METHODOLOGY OF COMPARATIVE EVALUATION OF DIFFERENT TYPES OF JET EDUCATIONAL-TRAINING(EDUCATIONAL-BATTLE) PLANES
}

\author{
O. Leontiev, D. Berdochnik, A. Berdochnik
}

On this time a jet educational-battle plane of L-39C is the basic means of aerotechics for providing of base educational flight education of students of flying profile of studies the supply of the appointed tenure of employment of that approaches the maximum state whereupon them further exploitation must be stopped not depending on their technical state. To Tom, for providing of the continuous training of flying personnels there is an issue of the day of updating of existent park of educational air-units (subdivisions) by modern jet educational-battle planes. For a choice as an educational-battle airplane due to that it is expedient to renew the existent park of airplanes of this class in the best method, necessary methodology of comparative evaluation of types of airplanes in relation to the degree of their fitness for the use in base educational flight education of students. The analysis of existent methodical approaches is conducted for the comparative evaluation of jet educational-battle (educational-training) planes and defects are analysed at the practical use each of methodical approach. Present technical information and information generators are analysed that a producer gives at registration of technical suggestion, the list of descriptions of airplane, that can be included to the renewed factor space of initial data of the improved qualimetric model, is formed as a result. The way of improvement of existent methodology of determination of qualimetric value of degree of adjusted is found to base flight education of students by the way of replacement of entrance factors of initial space of methodology on auxiliary interpolation models, initial data of that were entered by descriptions of airplane, values of that are accessible from present scientific and technical information generators. The conducted estimation of the got auxiliary models is on the terms of exactness of approximation and faithful reflection of tendencies of behavior of factors at the change of values of model parameters, that allows to recommend the built auxiliary models for the practical use. In future it is planned to build the auxiliary mathematical models of other partial indexes for the improvement of existent qualimetric models of educational properties of jet educational-battle (educational-training) planes on the basis of updating of them factor space.

Keywords: comparative assessment, training (combat training) aircraft, factor space, qualimetric model, auxiliary interpolation model. 